\title{
Study of X-phase formation on Cu-Al-Ni shape memory alloys with Ti addition
}

\author{
Wee Ying Ci ${ }^{1, \text { a }}$, Tuty Asma Abu Bakar ${ }^{1, b^{*}}$, Esah Hamzah ${ }^{1, c}$ and Safaa Najah \\ Saud $^{2, d}$ \\ ${ }^{1}$ Faculty of Mechanical Engineering, Universiti Teknologi Malaysia, \\ Skudai, 81310, Johor, Malaysia \\ ${ }^{2}$ Faculty of Information Science and Engineering, \\ Management and Science University, \\ 40100 Shah Alam, Malaysia

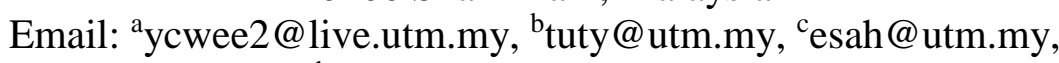 \\ dsafaa_najah@msu.edu.my
}

\begin{abstract}
$\mathrm{Cu}$-based shape memory alloys are used in various applications due to their attractive shape memory effect, easier process and cheaper cost. $\mathrm{Cu}-\mathrm{Al}-\mathrm{Ni}$ SMAs are one of the well-known $\mathrm{Cu}$-based shape memory alloys because of their capability in demonstrating shape memory effect, damping behaviour, and thermoelastic martensitic transformation. In this paper, the effect of $\mathrm{Ti}$ addition on the phase transformation temperatures and microstructures of $\mathrm{Cu}-\mathrm{Al}-\mathrm{Ni} \mathrm{SMA}$ was investigated. The $\mathrm{Cu}-\mathrm{Al}-\mathrm{Ni}$ alloy specimens were casted with the addition of titanium (Ti) using an induction furnace. Transformation temperature of the alloy was studied by differential scanning calorimetry. The evolution of the phases and microstructures was investigated by using the field emission scanning electron microscopy corresponding with energy dispersive spectroscopy and X-ray diffraction. It was found that the addition of $\mathrm{Ti}$ in the $\mathrm{Cu}-\mathrm{Al}-\mathrm{Ni} \mathrm{SMAs}$ has increased the transformation temperatures. The results revealed that the addition of $\mathrm{Ti}$ led to the formation of a new phase into the microstructure known as X-phase. From the XRD result, it was indicated that the $\mathrm{X}$-phase was $\mathrm{AlNi}_{2} \mathrm{Ti}$ and $\mathrm{Cu}_{3} \mathrm{Ti}$ compounds. It was also found that the alloy with $0.7 \mathrm{wt} \% \mathrm{Ti}$ has produced the most effective outcome of the transformation temperature $\left(\mathrm{M}_{\mathrm{s}}: 233.16^{\circ} \mathrm{C}, \mathrm{M}_{\mathrm{f}}: 225.67^{\circ} \mathrm{C}, \mathrm{A}_{\mathrm{s}}: 229.85^{\circ} \mathrm{C}, \mathrm{A}_{\mathrm{f}}: 239.25^{\circ} \mathrm{C}\right)$ due to the presence of $\mathrm{X}$-phase in the microstructure. Further study will be carried out to investigate the application of this material and focus on the application of the material in damping application.
\end{abstract}

Keywords: Shape memory alloys; Cu-Al-Ni SMA; X-phase.

\section{INTRODUCTION}

Shape memory alloys (SMAs) tend to be unique materials because they can return to their original shape after deformation upon heating or releasing stress. There are two peculiar properties called the shape memory effect and Pseudoelasticity or superelasticity that make the materials unique due to the phase transformation between two phases. The materials only perform their "remembering" effects when the temperature given to the material is above their transformation temperature [1-3]. The development of SMAs leads to their potential uses in medical applications, MEMS, aerospace, and damping and civil applications [4-7]. There are two common types of SMAs which are NiTi and $\mathrm{Cu}$-based 
shape memory alloys. NiTi alloys usually exhibit better shape memory properties compared to $\mathrm{Cu}$-based SMA; however, they are very expensive and difficult to fabricate $[8,9]$. Cu-based SMAs tend to be more attractive due to low cost, easy to process, high thermal stability and shape memory recovery $[10,11]$. Among Cu-based shape memory alloys, $\mathrm{Cu}-\mathrm{Al}-\mathrm{Ni}$ alloys are considered to be more attractive for high-temperature application due to the small thermal hysteresis and their transformation temperature at around $200{ }^{\circ} \mathrm{C}$ compared to $\mathrm{Cu}-\mathrm{Zn}-\mathrm{Al}$ and $\mathrm{Ni}-\mathrm{Ti}$ alloys where the maximum transformation temperature is around $100{ }^{\circ} \mathrm{C}$ [12]. The shape memory effects of Cu-Al$\mathrm{Ni}$ alloys rely on the composition of aluminium and nickel content while the composition is about 11-14 mass \% and 3-5 mass \% for aluminium and nickel, respectively [1]. Controlling the amount of aluminium and nickel content in order to affect their transformation temperature and properties as the transformation temperatures is particularly very sensitive to the concentration changes [13]. Furthermore, the martensite phases of $\mathrm{Cu}$ based SMAs can be established such as $\alpha_{1}{ }^{\prime}, \beta_{1}{ }^{\prime}, \beta_{1}{ }^{\prime \prime}$ and $\gamma_{1}{ }^{\prime}$ from their parent phase, $\beta_{1}$ where the phase transformation depends on chemical composition, test temperature, application of stress, and crystal orientation [14-16]. Yet, for $\mathrm{Cu}-\mathrm{Al}-\mathrm{Ni}$ SMAs, two martensite structures $\beta_{1}{ }^{\prime}$ and $\gamma_{1}{ }^{\prime}$ are typically obtained and the formations of these structures are strongly influenced by $\mathrm{Al}$ and $\mathrm{Ni}$ compositions and combination of the percentage that depends on the required characteristics for the application.

Nonetheless, the ternary alloys of $\mathrm{Cu}-\mathrm{Al}-\mathrm{Ni}$ SMAs structures are ductile in single crystal only and generally brittle and have low recovery strain which causes limit to practical applications $[17,18]$. Normally, $\beta$ phase of $\mathrm{Cu}-\mathrm{Al}-\mathrm{Ni}$ alloy is caused by intergranular fracture due to its high elastic anisotropy and regular large grain sizes. In order to overcome this problem, grain size refinement with the addition of alloying element, precipitation hardening or heat treatment can be used to improve the mechanical properties and increase their workability and ductility [19-22]. Addition of alloying element such as $\mathrm{Ti}, \mathrm{Mn}, \mathrm{V}, \mathrm{Nb}, \mathrm{B}$ or varying the compositions of $\mathrm{Al}$ or $\mathrm{Ni}$ is one of the methods to increase the ductility and refine the grain size of these alloys [23]. Sugimoto proved that the addition of the fourth element $\mathrm{Ti}$ to the ternary $\mathrm{Cu}-\mathrm{Al}-\mathrm{Ni}$ alloy obtained small equiaxed grains compared to the formation of large grains in the ternary cast alloy and produced the fine spherical particles so-called the X-phase [24, 25]. The aim of this paper is to study the effect of Ti additions to $\mathrm{Cu}-\mathrm{Al}-\mathrm{Ni}$ SMAs on the phase transformation characteristics and microstructures using differential scanning calorimeter (DSC), field emission scanning electron microscopy (FESEM), X-ray diffraction (XRD), and energy dispersive spectroscopy (EDS).

\section{METHODS AND MATERIALS}

$\mathrm{Cu}-13 \mathrm{wt} \% \mathrm{Al}-3.5 \mathrm{wt} \% \mathrm{Ni}$ with the addition of $0.7 \mathrm{wt} \% \mathrm{Ti}$ and $1.3 \mathrm{wt} \% \mathrm{Ti}$ were produced by melting the pure metals of $\mathrm{Cu}(99.999 \%), \mathrm{Al}(99.999 \%), \mathrm{Ni}(99.95 \%)$, and $\mathrm{Ti}(99.95 \%)$ in silicon carbide crucible at a temperature of $1300{ }^{\circ} \mathrm{C}$ as shown in Figure 1 . The ingot was homogenised at $900{ }^{\circ} \mathrm{C}$ for 30 minutes and then quenched in water in order to form the martensite. The cast ingot was cut into pieces for characterisation. The chemical compositions for the $\mathrm{Cu}-\mathrm{Al}-\mathrm{Ni}-\mathrm{Ti} \mathrm{SMAs}$ used inductively coupled plasma mass spectrometry (ICP-MS) as shown in Table 1. The microstructures of the specimens were observed by field emission scanning electron microscopy corresponding with the energy dispersive spectroscopy. The phase and crystal structure of X-phase were determined using a D5000 Siemens X-Ray diffractometer fitted with $\mathrm{CuK} \alpha \mathrm{X}$-ray source with a locked couple mode, $2 \theta$ range between $30-75^{\circ}$, and $0.05^{\circ}$ sec- 1 as the scanning step. In 
order to investigate the microstructure of the alloys, the quenched specimens were ground with different grit sizes of SiC papers with the following order of $200 \mu \mathrm{m}, 500 \mu \mathrm{m}$, and $1000 \mu \mathrm{m}$ and polished, then followed by being etched in solution of $10 \mathrm{ml} \mathrm{HCl}, 2.5 \mathrm{~g}$ ferric chloride acid $\left(\mathrm{FeCl}_{3} \cdot 6 \mathrm{H}_{2} \mathrm{O}\right)$, and $48 \mathrm{ml}$ methanol $\left(\mathrm{Ch}_{3} \mathrm{OH}\right)$. For the phase transformation temperatures, Perkin Elmer Pyris 6-differential scanning calorimetry (DSC) was conducted with $10{ }^{\circ} \mathrm{C} / \mathrm{min}$ for heating and cooling rates along with an inert nitrogen atmosphere with the flow rate of $20 \mathrm{ml} / \mathrm{min}$.
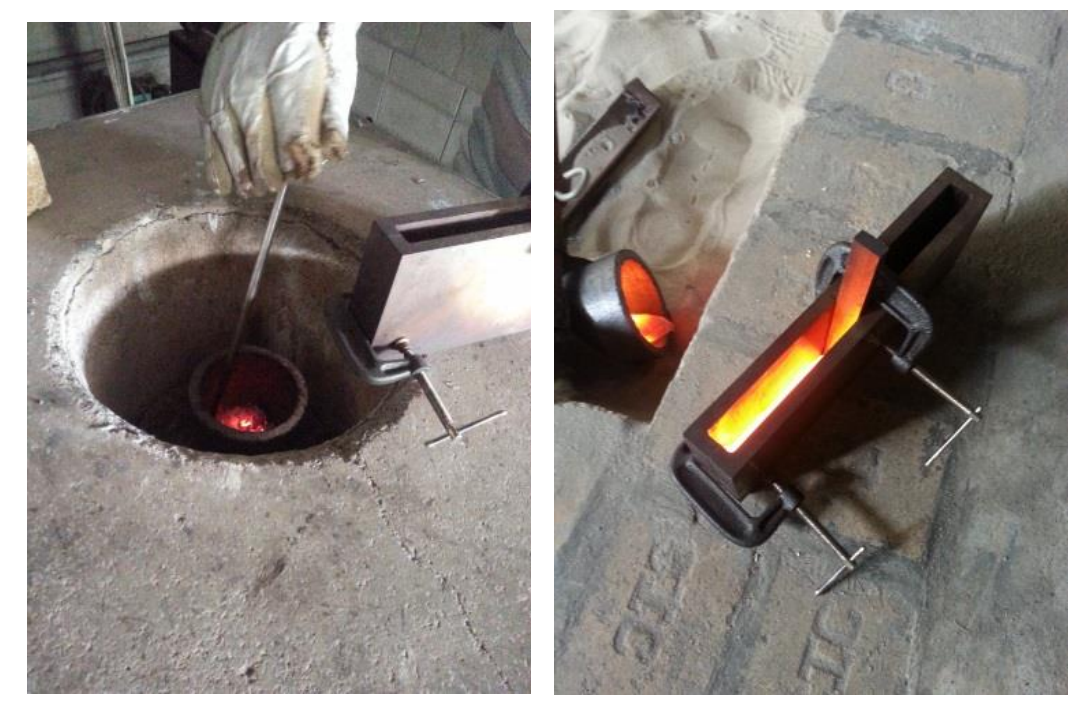

Figure 1 Casting process.

Table 1. Chemical composition of Cu-Al-Ni SMAs (wt. \%).

\begin{tabular}{lllll}
\hline Alloy & $\mathrm{Cu}$ & $\mathrm{Al}$ & $\mathrm{Ni}$ & $\mathrm{Ti}$ \\
\hline $\mathrm{A}$ & 83.5 & 13 & 3.5 & - \\
$\mathrm{B}$ & 82.8 & 13 & 3.5 & 0.7 \\
$\mathrm{C}$ & 82.2 & 13 & 3.5 & 1.3 \\
\hline
\end{tabular}

\section{RESULTS AND DISCUSSION}

The transformation temperatures of the alloys were determined by using DSC. Figure 2 shows the results of transformation temperature of $\mathrm{Cu}-\mathrm{Al}-\mathrm{Ni} \mathrm{SMA}$ with different $\mathrm{Ti}$ additions for the heating and cooling processes. The results of martensite transformation temperature $\left(\mathrm{M}_{\mathrm{s}}\right.$ and $\left.\mathrm{M}_{\mathrm{f}}\right)$ and austenite transformation temperature $\left(\mathrm{A}_{\mathrm{s}}\right.$ and $\left.\mathrm{A}_{\mathrm{f}}\right)$ from the DSC curves are recorded in Table 2. The changes of the characteristic temperature of $\mathrm{Cu}$ Al-Ni SMAs are due to the variations in their chemical composition $[10,13]$. Moreover, the addition of alloying element will lead to either increase or decrease in transformation temperatures [26]. As shown in Figure 2, it was observed that the heating and cooling curves were shifted to the right (higher transformation temperature) where the transformation temperature increased from base alloy, $1.3 \mathrm{wt} \% \mathrm{Ti}$ addition, and $0.7 \mathrm{wt} \%$ $\mathrm{Ti}$ addition. It can be explained that the transformation temperature increased when there was an addition of Ti to the alloy [27]. Furthermore, $0.7 \mathrm{wt} \% \mathrm{Ti}$ addition had the highest transformation temperature due to its high density of X-phase existence [28, 29]. Therefore, it can also be determined that the transformation temperature increases when there is a presence of $\mathrm{X}$-phase. Apart from that, there was a small peak on the cooling 
curve for each of the alloys after the main peak and this phenomenon did not happen in the heating curve. This is because the inter-martensitic transformation occurred and can be inhibited during heating.

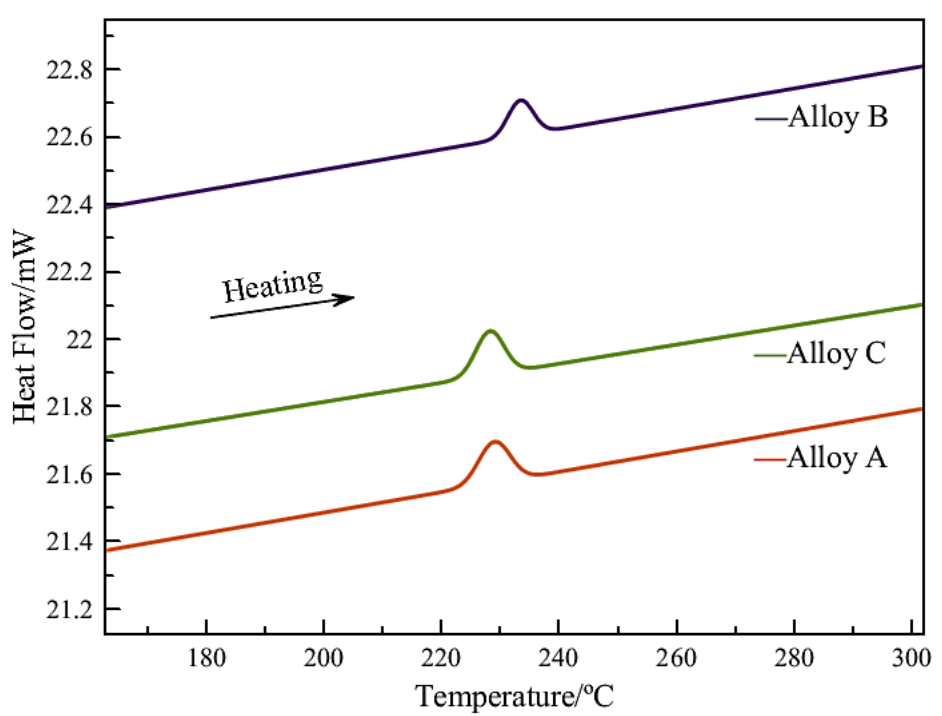

(a)

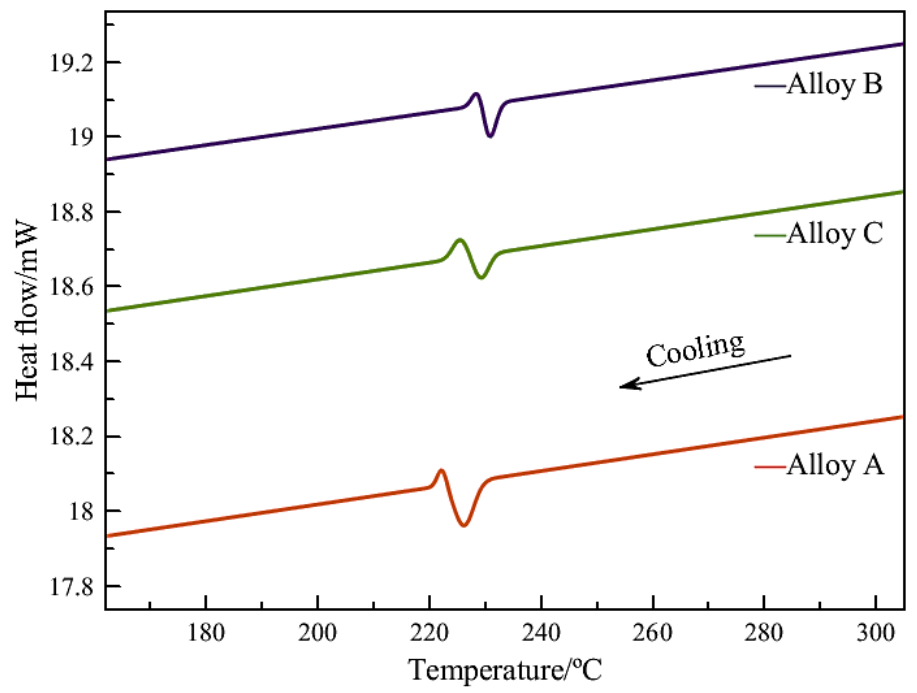

(b)

Figure 2. DSC curves of the Cu-Al-Ni SMA with different compositions of Ti addition (a) Heating, and (b) Cooling.

Table 2. Transformation temperatures of Cu-Al-Ni SMAs.

\begin{tabular}{ccccc}
\hline Alloy & \multicolumn{5}{c}{ Transformation Temperatures $/{ }^{\circ} \mathrm{C}$} \\
\cline { 2 - 5 } & $\mathrm{M}_{\mathrm{s}}$ & $\mathrm{M}_{\mathrm{f}}$ & $\mathrm{A}_{\mathrm{s}}$ & $\mathrm{A}_{\mathrm{f}}$ \\
\hline $\mathrm{A}$ & 225.03 & 220.21 & 223.61 & 235.02 \\
$\mathrm{~B}$ & 233.16 & 225.67 & 229.85 & 239.25 \\
$\mathrm{C}$ & 231.96 & 222.54 & 223.70 & 234.91 \\
\hline
\end{tabular}




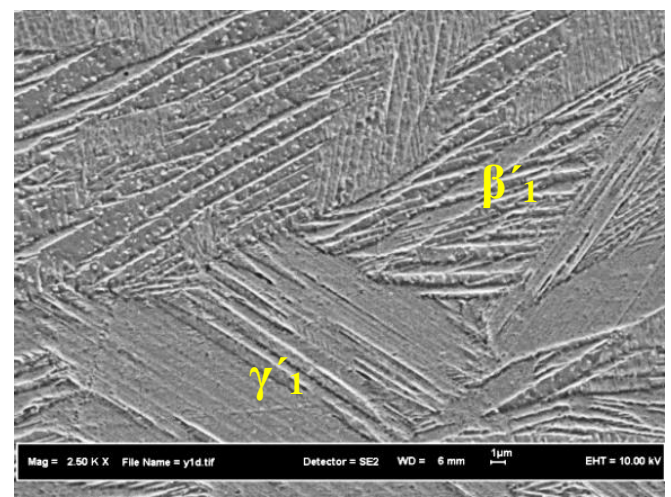

(a)

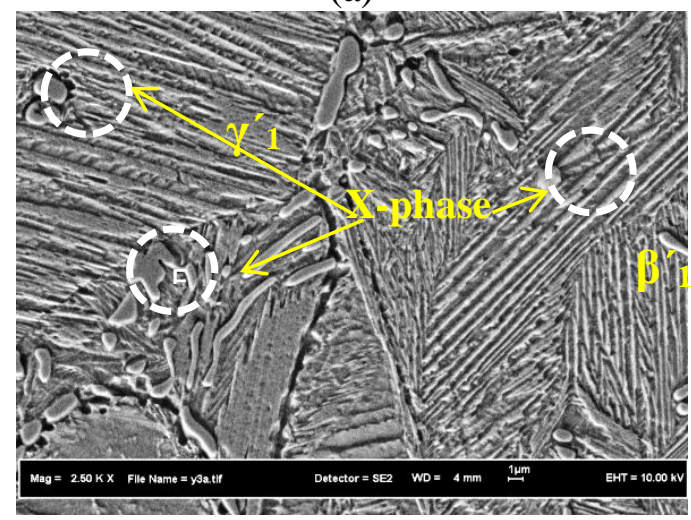

(b)

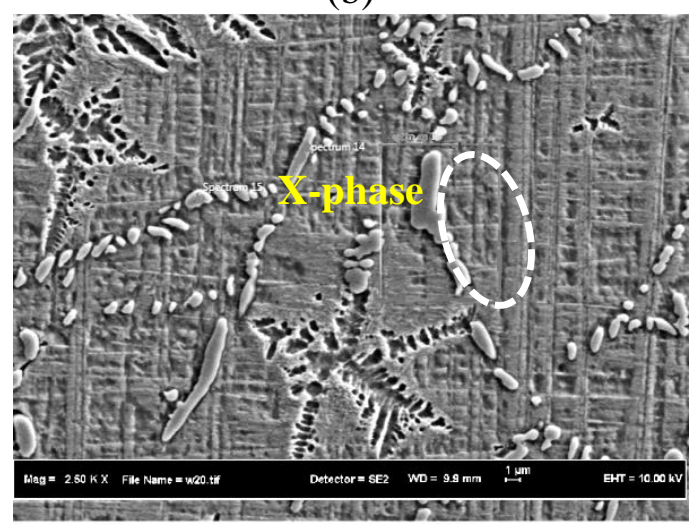

(c)

Figure 3. FESEM micrographs (a) $\mathrm{Cu}-\mathrm{Al}-\mathrm{Ni}$, (b) $\mathrm{Cu}-\mathrm{Al}-\mathrm{Ni}-0.7 \mathrm{wt} \% \mathrm{Ti}$, (c) $\mathrm{Cu}-\mathrm{Al}-\mathrm{Ni}-$ $1.3 \mathrm{wt} \% \mathrm{Ti}$.

In order to study the effect of $\mathrm{Ti}$ addition to the $\mathrm{Cu}-\mathrm{Al}-\mathrm{Ni} \mathrm{SMA}$, the microstructure was investigated by using FESEM as shown in Figure 3. From the figure, martensite phase can be seen obviously for all the microstructures in different morphologies and many precipitations are formed in Figure 3(b) and 3(c) which consist of the addition of the fourth element of $0.7 \mathrm{wt} \% \mathrm{Ti}$ and $1.3 \mathrm{wt} \% \mathrm{Ti}$, respectively. Two different types of martensite could be observed among the three alloys; the self-accommodating zig-zag morphology groups of $\beta_{1}{ }^{\prime}$ martensite and course variants $\gamma_{1}{ }^{\prime}$ martensite [30]. As reported by Tadaki, the martensite phase was disordered $18 \mathrm{R}\left(\beta_{1}{ }^{\prime}\right)$ for $11-13 \mathrm{wt} \% \mathrm{Al}$ and $2 \mathrm{H}\left(\gamma_{1}{ }^{\prime}\right)$ for more than $13 \mathrm{wt} \% \mathrm{Al}$ [31]. Therefore, both coexisted martensite phases were considered to be present. Furthermore, there was a lot of precipitation found in the microstructures of Figure 3(b) and 3(c) which accumulated at the grain boundaries and 
restricted grain growth. The grain size of $\mathrm{Cu}-\mathrm{Al}-\mathrm{Ni}, \mathrm{Cu}-\mathrm{Al}-\mathrm{Ni}-0.7 \mathrm{wt} \% \mathrm{Ti}$, and $\mathrm{Cu}-\mathrm{Al}-\mathrm{Ni}-$ $1.3 \mathrm{wt} \% \mathrm{Ti}$ was about $1500 \mu \mathrm{m}, 700 \mu \mathrm{m}$, and $900 \mu \mathrm{m}$, respectively. In other words, these results proved that the grain size was reduced after Ti addition. This is attributed to the formation of precipitates that abstained the nucleation and grain growth by the pinning effect [32]. Therefore, this shows that the addition of Ti contributed to grain size refinement. Figure 3(b) shows the microstructure of $\mathrm{Cu}-\mathrm{Al}-\mathrm{Ni}$ with $0.7 \mathrm{Ti}$ addition, where the precipitations were formed with an irregular shape [29] and distributed in the matrix, on grain boundaries or inside the grains. In addition, these precipitates so-called X-phase $[28,33]$ represented the white dots in the microstructure. With the increasing composition of Ti to $1.3 \mathrm{wt} \%$ observed in Figure 3(c), the precipitations accumulated and became more elongated or rod-like, which was not peculiarly located at grain boundaries [20]. Furthermore, the volume fraction of X-phase increased with the increasing percentage of Ti. It also indicated that the precipitation density increased with the increasing percentage of Ti. Corresponding to the analysis of EDS on the X-phase area shown in Figure 4, it was indicated that the concentration of $\mathrm{Ti}$ in X-phase area was rich (spectrum 1), and the microstructure also consisted of $\mathrm{Ti}$ (spectrum 2) which showed that Ti was diffused in the microstructure and also created the grain boundaries. These boundaries became the obstacle to the growth of $\beta_{1}{ }^{\prime}$. Therefore, the reduction of grain size also led to a reduction of martensite plate boundaries due to the interface mobility.

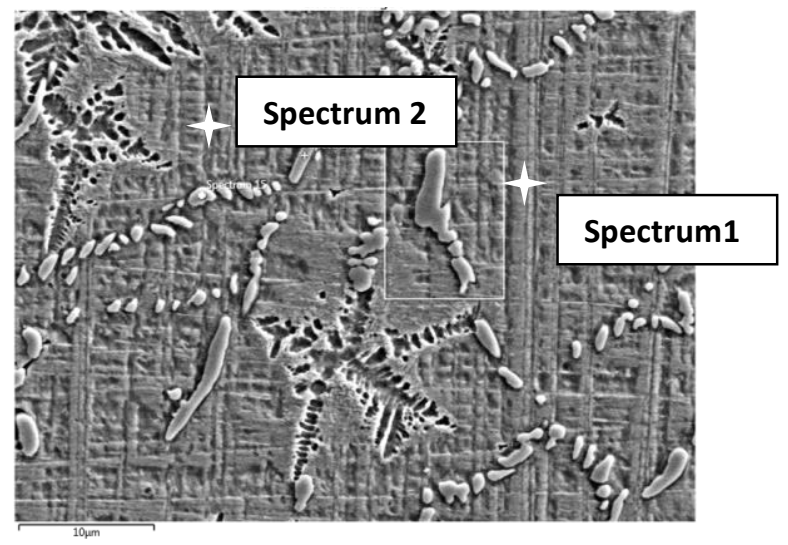

(a)

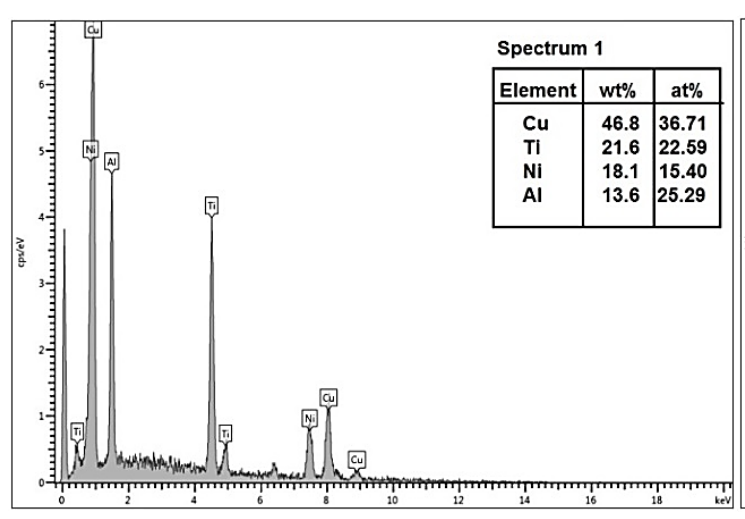

(b)

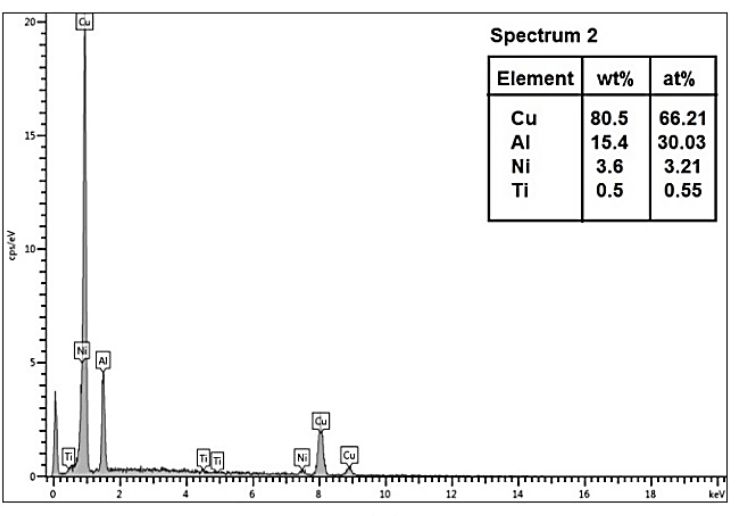

(c)

Figure 4. EDS analysis of Cu-Al-Ni-1.3wt\% Ti (a) Micrograph, (b) Spectrum 1, (c) Spectrum 2. 
Figure 5 shows $\mathrm{X}$-ray diffraction patterns of $\mathrm{Cu}-\mathrm{Al}$-Ni SMA with and without the addition of $\mathrm{Ti}$ at room temperature in order to investigate its effect on the phase transformation characteristics. In $\mathrm{Cu}-\mathrm{Al}$ alloys, the martensite phase changed from $\beta^{\prime}$ to $\gamma_{1}{ }^{\prime}$ and $\beta_{1}{ }^{\prime}$ with increasing Al content. According to the matching process with the standard of JCPDS, there were two martensite phases, $\gamma_{1}{ }^{\prime}$ and $\beta_{1}{ }^{\prime}$ in $\mathrm{Cu}-\mathrm{Al}-\mathrm{Ni}$ SMA that can be confirmed by proving the peak pattern. The peak of (200) represented $\gamma_{1}{ }^{\prime}$ martensite and generally the other peaks were performed as $\beta_{1}{ }^{\prime}$ martensite. By comparing the diffraction patterns for alloy $\mathrm{A}, \mathrm{B}$, and $\mathrm{C}$, there was a slight change after the addition of Ti. The peaks of (122), (202), (0018), (128), (1210), (2010), (208), (040), and (320) which represented the $\beta_{1}{ }^{\prime}$ martensite for alloy $\mathrm{B}$ and alloy $\mathrm{C}$ were shifted to the left. This is attributed to the Ti addition. Furthermore, there were two peaks that appeared at 2-theta of $57.99^{\circ}$ and $63.54^{\circ}$ which were (212) and (400), respectively in alloy B and C. This indicated that the compound of $\mathrm{Cu}_{3} \mathrm{Ti}$ and $\mathrm{AlNi}_{2} \mathrm{Ti}$ belonged to X-phase.

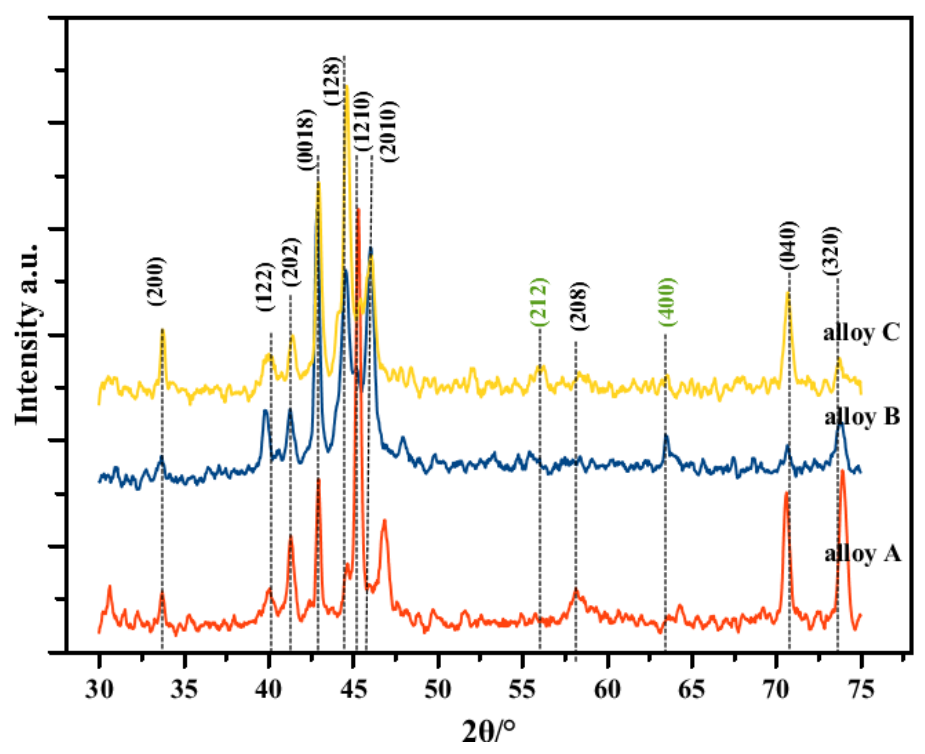

Figure 5. X-ray diffraction patterns of alloy $\mathrm{A}(\mathrm{Cu}-\mathrm{Al}-\mathrm{Ni})$, alloy $\mathrm{B}(\mathrm{Cu}-\mathrm{Al}-\mathrm{Ni}-$ $0.7 \mathrm{wt} \% \mathrm{Ti})$, and alloy $\mathrm{C}(\mathrm{Cu}-\mathrm{Al}-\mathrm{Ni}-1.3 \mathrm{wt} \% \mathrm{Ti})$.

Table 3. Lattice Parameters of $\mathrm{Cu}-\mathrm{Al}-\mathrm{Ni}$ SMA with and without addition of Ti.

\begin{tabular}{lllll}
\hline Alloy & $\mathrm{a} / \AA$ & $\mathrm{b} / \AA$ & $\mathrm{c} / \AA$ & $\mathrm{a} / \mathrm{b}$ \\
\hline $\mathrm{A}$ & 4.421 & 5.246 & 37.914 & 0.845 \\
$\mathrm{~B}$ & 4.434 & 5.344 & 37.823 & 0.857 \\
$\mathrm{C}$ & 4.440 & 5.310 & 38.012 & 0.850 \\
\hline
\end{tabular}

XRD analysis confirmed the presence of the monoclinic phase of lattice parameters for all alloys and is shown in Table 3. The lattice parameters can be determined by the following relation [34]:

$$
\frac{1}{d^{2}}=\frac{1}{a^{2}}\left(\frac{h^{2}}{\sin ^{2} \beta}\right)+\frac{k^{2}}{b^{2}}+\frac{1}{c^{2}}\left(\frac{l^{2}}{\sin ^{2} \beta}\right)-\frac{2 h l \cos \beta}{a c \sin ^{2} \beta}
$$


where $d$ is the spacing distance; $a, b$, and $c$ are lattice parameters, and hkl are miller indices; and $\beta$ is the angle. The lattice parameters were determined from the XRD patterns as presented in Table 3 . The $a / b$ ratio was also calculated and is presented in Table 3 . Lattice parameters were studied on the monoclinic structure of $\gamma_{1}{ }^{\prime}$ and $\beta_{1}{ }^{\prime}$ phases from XRD patterns which are similar to the previous works $[26,29]$. This confirms that the structure was monoclinic $18 \mathrm{R}$ martensite as the $\mathrm{a} / \mathrm{b}$ ratio was less than $\sqrt{3} / 2$ [35]. This is due to the high temperature of $\beta$ phase developed into a $\mathrm{DO}_{3}$ structure and then further transformed into 18R martensite structure during rapid cooling process [36].

\section{CONCLUSIONS}

The purpose of the current study was to determine the addition of alloying element, Ti to the $\mathrm{Cu}-\mathrm{Al}-\mathrm{Ni}$ shape memory alloy. The effect of this element addition on the transformation temperature and microstructure was investigated and the conclusions are as follows;

i) There was a shift in the transformation temperatures of the alloy with Ti addition. Significant changes on the transformation temperatures $\left(\mathrm{M}_{\mathrm{s}}: 233.16^{\circ} \mathrm{C}, \mathrm{M}_{\mathrm{f}}\right.$ : $225.67^{\circ} \mathrm{C}, \mathrm{A}_{\mathrm{s}}: 229.85^{\circ} \mathrm{C}, \mathrm{A}_{\mathrm{f}}: 239.25^{\circ} \mathrm{C}$ ) were obtained for the alloys with 0.7 mass $\%$ of $\mathrm{Ti}$ additions due to the presence of $\mathrm{X}$-phase in the microstructure.

ii) The martensite obtained was found as 18R type with monoclinic structure from $\mathrm{XRD}$ result. A new phase namely, X-phase was found present in the microstructure with the addition of Ti. The compound of $\mathrm{X}$ phase were indicated as $\mathrm{AlNi}_{2} \mathrm{Ti}$ and $\mathrm{Cu}_{3} \mathrm{Ti}$ from XRD. In addition, the alloy with $1.3 \mathrm{wt} \%$ Ti created the elongated $\mathrm{X}$-phase at the grain boundaries.

Further study will be carried out to investigate the application of this material and focus on the application of the material in damping application. Dynamic mechanical analysis (DMA) and cyclic test will be conducted to measure the damping parameters.

\section{ACKNOWLEDGEMENTS}

The authors gratefully acknowledge the financial support for this research provided by Universiti Teknologi Malayia, Research University Grant - Tier 1 under vote number 13H72 and Ministry of Higher Education.

\section{REFERENCES}

[1] Otsuka K, Wayman CM. Shape memory materials. Cambridge: Cambridge University Press; 2002.

[2] Lexcellent C. Shape-Memory Alloys Handbook: Wiley; 2013.

[3] Frémond M. Shape Memory Alloy. Shape Memory Alloys. Vienna: Springer Vienna; 1996. p. 1-68.

[4] Wu MH, Schetky L. Industrial applications for shape memory alloys. Proceedings of the International Conference on Shape Memory and Superelastic Technologies; 2000. p. 171-82.

[5] Song G, Ma N, Li HN. Applications of shape memory alloys in civil structures. Engineering Structures. 2006;28:1266-74.

[6] Sawaguchi T, Maruyama T, Otsuka H, Kushibe A, Inoue Y, Tsuzaki K. Design Concept and Applications of Fe-Mn-Si-Based Alloys--from Shape-Memory to Seismic Response Control. Materials Transactions. 2016;57:283-93. 
[7] Machado LG, Savi MA. Medical applications of shape memory alloys. Brazilian Journal of Medical and Biological Research. 2003;36:683-91.

[8] Duerig TW, Melton KN, Stockel D, Wayman CM. Engineering Aspects of Shape Memory Alloys: Books on Demand; 1990.

[9] Wu SK, Lin HC, Chen CC. A study on the machinability of a Ti49.6Ni50.4 shape memory alloy. Materials Letters. 1999;40:27-32.

[10] Tadaki T. Cu based shape memory alloys, Shape memory materials. Cambridge: Cambridge University Press; 2002.

[11] Funakubo H. Shape memory alloys. 1984.

[12] Stöckel D. The Shape Memory Effect-phenomenon, alloys and applications. NDC, Nitinol Devices \& Components Company, California Fremont, www nitinol-europe com/pdfs/smemory pdf 1995.

[13] Recarte V, Pérez-Sáez RB, San Juan J, Bocanegra EH, Nó ML. Influence of Al and $\mathrm{Ni}$ concentration on the Martensitic transformation in $\mathrm{Cu}-\mathrm{Al}-\mathrm{Ni}$ shapememory alloys. Metallurgical and Materials Transactions A. 2002;33:2581-91.

[14] Suru M-G, Lohan N-M, Pricop B, Mihalache E, Mocanu M, Bujoreanu L-G. Precipitation effects on the martensitic transformation in a cu-al-ni shape memory alloy. Journal of Materials Engineering and Performance. 2016;25:1562-9.

[15] Friend CM. The effect of aluminium content on the martensite phase stabilities in metastable CuAlNi alloys. Scripta Metallurgica. 1989;23:1817-20.

[16] Miyazaki S. Development and characterization of shape memory alloys. shape memory alloys. Vienna: Springer Vienna; 1996. p. 69-147.

[17] Palánki Z, Daróczi L, Lexcellent C, Beke DL. Determination of the equilibrium transformation temperature (T0) and analysis of the non-chemical energy terms in a CuAlNi single crystalline shape memory alloy. Acta Materialia. 2007;55:182330.

[18] Gastien R, Corbellani CE, Sade M, Lovey FC. Thermal and pseudoelastic cycling in $\mathrm{Cu}-14.1 \mathrm{Al}-4.2 \mathrm{Ni}$ (wt\%) single crystals. Acta Materialia. 2005;53:1685-91.

[19] Sobrero CE, La Roca P, Roatta A, Bolmaro RE, Malarría J. Shape memory properties of highly textured $\mathrm{Cu}-\mathrm{Al}-\mathrm{Ni}-(\mathrm{Ti})$ alloys. Materials Science and Engineering: A. 2012;536:207-15.

[20] Adachi K, Shoji K, Hamada Y. Formation of X Phases and origin of grain refinement effect in $\mathrm{Cu}-\mathrm{Al}-\mathrm{Ni}$ shape memory alloys added with titamium. ISIJ International. 1989;29:378-87.

[21] Saiji M, Masami H, Ryuichiro O, Francisco Eiichi F. Improvement of ductility of melt spun $\mathrm{Cu}-\mathrm{Al}-\mathrm{Ni}$ shape memory alloy ribbons by addition of Ti or Zr. Japanese Journal of Applied Physics. 1983;22:L528.

[22] Odusote J, Adeleke A, Ajayi P. Mechanical properties and microstructure of precipitation-hardening $\mathrm{Al}-\mathrm{Cu}-\mathrm{Zn}$ alloys. International Journal of Automotive and Mechanical Engineering. 2015;12:3033-42.

[23] Saud S, Hamzah E, Abubakar T, Hosseinian R. A review of alloying element on the microstructure and mechanical properties of $\mathrm{Cu}-\mathrm{Al}-\mathrm{Ni}$ shape memory alloys. Jurnal Teknologi. 2013;64:51-6.

[24] Sugimoto K, Kamei K, Matsumoto H, Komatsu S, Akamatsu K, Sugimoto T. Grain-refinement and the related phenomena in quaternary $\mathrm{Cu}-\mathrm{Al}-\mathrm{Ni}$-Ti shape memory alloys J Phys Colloques. 1982;43:C4-761-C4-6.

[25] Lee JS, Wayman CM. Grain Refinement of a $\mathrm{Cu}-\mathrm{Al}-\mathrm{Ni}$ shape memory alloy by Ti and Zr Additions. Transactions of the Japan Institute of Metals. 1986;27:58491. 
[26] Sampath V. Studies on the effect of grain refinement and thermal processing on shape memory characteristics of $\mathrm{Cu}-\mathrm{Al}-\mathrm{Ni}$ alloys. Smart Materials and Structures. 2005;14:S253.

[27] Dutkiewicz J, Czeppe T, Morgiel J. Effect of titanium on structure and martensic transformation in rapidly solidified $\mathrm{Cu}-\mathrm{Al}-\mathrm{Ni}-\mathrm{Mn}-\mathrm{Ti}$ alloys. Materials Science and Engineering: A. 1999;273-275:703-7.

[28] Adachi K, Hamada Y, Tagawa Y. Crystal structure of the X-phase in grain-refined Cu-Al-Ni-Ti shape memory alloys. Scripta Metallurgica. 1987;21:453-8.

[29] Saud SN, Hamzah E, Abubakar T, Zamri M, Tanemura M. Influence of Ti additions on the martensitic phase transformation and mechanical properties of $\mathrm{Cu}-\mathrm{Al}-\mathrm{Ni}$ shape memory alloys. Journal of Thermal Analysis and Calorimetry. 2014;118:111-22.

[30] Sarı U, Aksoy İ. Electron microscopy study of $2 \mathrm{H}$ and $18 \mathrm{R}$ martensites in $\mathrm{Cu}-$ $11.92 \mathrm{wt} \%$ Al-3.78 wt\% $\mathrm{Ni}$ shape memory alloy. Journal of Alloys and Compounds. 2006;417:138-42.

[31] T.Tadaki. Cu-based shape memory alloys. 1998:97-116.

[32] Sure GN, Brown LC. The fatigue properties of grain refined $\beta-\mathrm{Cu} \mathrm{Al} \mathrm{Ni}$ strainmemory alloys. Scripta Metallurgica. 1985;19:401-4.

[33] Hurtado I, Ratchev P, Van Humbeeck J, Delaey L. A fundamental study of the $\chi$ phase precipitation in $\mathrm{Cu}-\mathrm{Al}-\mathrm{Ni}-\mathrm{Ti}-(\mathrm{Mn})$ shape memory alloys. Acta Materialia. 1996;44:3299-306.

[34] Xuan Q, Bohong J, Hsu TY, Zuyao X. The effect of martensite ordering on shape memory effect in a Copper-Zinc-Aluminium alloy. Materials Science and Engineering. 1987;93:205-11.

[35] Salzbrenner RJ, Cohen M. On the thermodynamics of thermoelastic martensitic transformations. Acta Metallurgica. 1979;27:739-48.

[36] Canbay CA, Karagoz Z. Effects of annealing temperature on thermomechanical properties of $\mathrm{Cu}-\mathrm{Al}-\mathrm{Ni}$ shape memory alloys. International Journal of Thermophysics. 2013;34:1325-35. 